\title{
ANALYSIS OF THE EFFECT OF ORGANIZATIONAL CULTURE ON PERFORMANCE OF EMPLOYEES (CASE STUDY OF THE KOMINFO OFFICE OF PARIAMAN CITY)
}

\author{
Rizki Afri Mulia', Rianda Prima Putri², Nika Saputra ${ }^{3}$ \\ ${ }^{1}$ Lecturer, STISIP Imam Bonjol \\ Email : rizki.afri.mulia@ stisipimambonjol.ac.id \\ ${ }^{2}$ Lecturer, STISIP Imam Bonjol \\ Email : rindra2201rianda@ gmail.com \\ ${ }^{3}$ Researcher, Universitas Ekasakti \\ Email : nikachaniago@rocketmail.com
}

\begin{abstract}
This study aims to analyze, Influence Organizational Culture Against Employee Performance At the Office of Communications and Information Technology of Pariaman. This research is a quantitative research that shows a causal relationship. The sample in this study were 47 employees. Data collection techniques used were observation, questionnaire and documentation. Data analysis techniques used are descriptive statistical analysis using percentages, averages, and standard deviations and for inferential statistical analysis using data normality tests, simple linear regression analysis, and product moment correlation analysis. The results of the study show that the organizational culture is in a very good category in terms of indicators, namely: Innovation and Courage to take risks; Attention to detail; Results oriented; Human oriented; Team oriented; Aggressive; and stable. Employee performance is in a very good category in terms of indicators of discipline of service personnel, responsibility of service personnel, ability of service personnel, politeness and friendliness of officers, based on simple linear regression analysis shows that there is an influence of organizational culture on employee performance at the Pariaman City Communication and Information Agency Pariaman City. From the results of product moment correlation analysis obtained a significant level of relationship between the influence of organizational culture on the performance of employees at the Office of Communication and Information Office of Pariaman City, Pariaman City with the Strong category.
\end{abstract}

Keywords: Organizational culture and employee performance 


\section{INTRODUCTION}

Humans as social beings basically have the nature to socialize, cooperate and need the existence of other humans (Abdullah, 2003; Children, 1995; Marcella, 2004; Soegandhi \& Sutanto, 2013; Suryana, 2011). Therefore, the existence of an organization is very much needed as a container that can gather or facilitate humans in socializing and working together. For this reason, human resources are a part that has an important role in an organization that is a planner in every organization's activities. Some human resource management activities such as procurement, training, employee motivation, assessment, discipline improvement and others. Human resources are assets that must be constantly considered to obtain human resources that have good performance, so they can develop organizations in various demands of society and the development of the times. In an effort to support the achievement of organizational goals, quality and professional human resources are also needed. Professional and quality human resources tend to have better performance, so efforts to improve the quality of human resources are very important to be considered by the leadership of the organization (Akib, 2008; Dharma \& Akib, 2009; Ismail, Sulur, Akib, \& Salam, 2016; Saggaf, Salam, Kahar, \& Akib, 2014).

In government organizations / public in Indonesia, the performance of government organizations is a very important thing to realize governance (good governance) and good governance (clean governance), as well as supporting the tasks of government to provide the best service to the public in accordance with his trademark as a government organization that is oriented toward public service (public service oriented) and not to look for profit (profit-oriented) (Azizy, 2007). Based on the views of the general public, one of the great challenges of government organizations today are implementing performance effectively and efficiently as currently government agencies identified with the performance of slow, complicated, convoluted and filled with Corruption, Collusion and Nepotism (Azizy, 2007; Moeljono, 2003; Nurbarani, 2009; Saputra, 2014). 
In order to improve the performance of qualified and professional employees one of the factors that is suitable to be applied in the work environment is organizational culture. Organizational culture can help employee performance, because it creates an extraordinary level of motivation for employees to provide the best ability to take advantage of the opportunities provided by the organization. To implement a suitable organizational culture in an organization, it is necessary to have the support and participation of all members in the scope of the organization.(Mulia 2019)

Pariaman City Communication and Information Office also does not want to be left behind in building an effective organizational culture in order to create better work results, work discipline and employee work quality. Government is required to have a clear and strategic vision and mission and every component in it is also required to be able to realize the vision and mission of the government. This vision and mission then gave birth to the values that were believed by members and reflected the culture of the organization.

The Office of Communication and Information as an institution that has the authority to manage information, has a role as a cultural transformer for the development of mandates and government relay holders in the future. In this institution the activities of the employees are expected to be able to play a role in realizing an information pattern and to be able to overcome all problems related to the quality of information and communication. Pariaman City Office of Communication and Information Office is responsible for developing, improving quality and coordinating information elements within the City of Pariaman.

Based on the results of observations made by researchers on 27 to 31 March 2019. Found several problems based on observations made by researchers, namely (1) some employees are still less responsible for the tasks and responsibilities assigned to him. As seen there are still many employees like to neglect their work. (2) some employees are still seen coming late to work and leaving the office during working hours. This can be seen that there are employees who are more concerned with personal matters outside the office. For example, leaving the office with the 
reason to attend family events that may not be so important. (3) employee performance is still not in line with the institution's expectations.

\section{RESEARCH METHODS}

This research is an associative research that is intended to explain the influence of organizational culture on employee performance at the Office of Communication and Information Office of Pariaman City, Pariaman City. This study basically will examine the hypothesis and make an interpretation of the effect of the independent variable on the dependent variable. To measure the variables of this study, a Likert scale questionnaire was used to be filled out by respondents in accordance with the indicator variables.(Mulia 2019)

The population in this study were 235 employees, while the number of employees sampled was 47 people. Researchers took $20 \%$ of the total population of 235 employees by using the Proportionate Random Sampling technique of 47 employees. Data collection techniques used in this study, namely through observation (observation), questionnaire (questionnaire), and documentation. The data analysis design used in this study is a descriptive statistical analysis design and inferential statistical analysis design.

\section{RESULTS OF DISCUSSION RESEARCH}

\section{Data analysis}

To determine the effect of organizational culture on employee performance, a questionnaire instrument was used as a data collection technique for variable $\mathrm{X}$ as an Organizational Culture variable and a questionnaire value for variable $\mathrm{Y}$ as Employee Performance. Furthermore, in testing hypotheses, quantitative tests are carried out using statistical formulas and computer software with the Statistical Standards Solusion Program (SPSS) which is considered relevant for data analysis which aims to find out how the level of influence of organizational culture on employee performance. 
1. Descriptive Statistical Analysis

To obtain the influence of Organizational Culture on Employee Performance at the Office of the Communication and Information Office of Pariaman City, Pariaman City, the two variables are made of frequency and percentage tables. Organizational culture variables (variable $\mathrm{X}$ ) are measured using very good, good, good enough, not good, very bad categories. While the employee performance variable (variable $\mathrm{Y}$ ) is measured by the same category that is very good, good, good enough, not good, not very good.

a. Description of Organizational Culture

Descriptive analysis is intended to find a picture of the culture of the organization at the Office of Communication and Information Office Pariaman City. The data presented in this study are data obtained as a result of scores from research questionnaires relating to organizational culture variables. Organizational culture variables consist of 7 (seven) indicators, namely: (1) Innovation and Courage to take risks; (2) Attention to detail; (3) Results-oriented; (4) Human-oriented; (5) Team oriented; (6) Aggressive; and (7) Stable.

Next, the seven indicators of organizational culture will be described as follows:

1) Innovation and courage to take risks

Employees have the drive to continue to innovate such as being creative in doing their work and dare to take risks and be responsible for the work they do. Mastering the understanding of innovation and the courage to take risks is an indicator of organizational culture variables in the very good category with a percentage rate of 83.04 percent.

2) Attention to Details

Employees have attention to details in carrying out their work such as paying attention to the position of accuracy, analyzing, and attention to every detail of the job. Mastering the understanding of attention to detail becomes an indicator of organizational culture variables that are in the very good category with a percentage level of 89.57 percent. 
3) Results Oriented

Employees are able to achieve targets or outcomes that have been determined and are able to manage their work, where the results of the work focus on the results to be achieved. Mastering results-oriented understanding is an indicator of organizational culture variables in the very good category with a percentage level of 91.01 percent.

4) Human Oriented

Employees provide good services to the people served, it will greatly affect both the people served and for employees in improving their performance. Mastering results-oriented understanding is an indicator of organizational culture variables in the very good category with a percentage level of 85.94 percent.

5) Team Oriented

The employees at the Kominfo Dinas Pariaman office have a good relationship among members so that they are able to work well with other members in completing work. Mastering team-oriented understanding as an indicator of organizational culture variables is in the very good category with a percentage level of 89.28 percent.

6) Aggressive

Employees at the Kominfo Dinas Pariaman office have their own initiative what should be done without having to wait for the leadership's order to be able to streamline work time. Mastering understanding about aggressiveness as an indicator of organizational culture variables is in the very good category with a percentage level of 83.19 percent.

7) Stable

Employees at the Pariaman City Office of Communication and Information Agency have the drive to continue to perform by providing satisfactory work to improve performance rather than to make performance decline and do not have the motivation to excel. Mastering the understanding of stable being an indicator of organizational culture 
variables with a very good category at the percentage level of 90.00 percent.

b. Employee Performance Description

Descriptive analysis is intended to determine the level of employee performance at the Office of Communication and Information Office Pariaman City. The data presented in this study are data obtained from the results of a research questionnaire with employee performance variables (Y). In the employee performance variable (y) the indicator consists of 4 (four), namely: (1) Discipline of service officers, (2) Responsibilities of service officers, (3) Ability of service officers, (4) Courtesy and friendliness of officers.

Furthermore, the four indicators of employee performance variables will be described as follows.

1) Discipline of Service Officers

Employees at the Pariaman City Communication and Information Office are able to work consistently, especially in terms of work time discipline. Come, rest, until the time to go home must be in accordance with the scheduled work time so that it gets good work results. Employees by applying the discipline of service personnel to be an indicator of employee performance variables with excellent categories are at a percentage level of 83.83 percent.

2) Responsibilities of Service Officers

Employees at the Pariaman City Communication and Information Office are able to have sensitivity with a full sense of responsibility. Employees who are able to take responsibility for their main tasks and functions are employees who have good work performance. Good work will be needed in the organization. the responsibility factor becomes an indicator by being in the very good category with a percentage level of 85.57 percent. 
3) The Capability of Service Officers

Employees at the Pariaman City Office of Communication and Information Service have good human resources with extensive knowledge in the field where they are placed and have knowledge in other fields. So when you get a job both work that is often done and new jobs that have not been done can be completed properly. Even though employees sometimes get lazy at work, this can be handled well. The ability of service personnel to be an indicator of employee performance variables is in the good category with a percentage level of 80.35 percent.

4) Courtesy and Friendliness of Officers.

Employees at the Pariaman City Office of Communication and Information Service are able to provide polite and friendly service to the parties being served as well as fellow colleagues and to the leadership. So that those who are served feel happy and comfortable when served and feel the satisfaction of the performance of the organization. Having the attitude of courtesy and friendliness of staff is an indicator of employee performance variables in the excellent category with a percentage of 89.22 percent.

\section{Discussion}

1. Organizational culture

The results of this study indicate that the level of organizational culture at the Office of Communication and Information Technology Pariaman City Pariaman City is in the category of Very Good. This is supported by indicators, namely: opinions (Robbins, 1996), what is meant by organizational culture are (1) Innovation and Courage to take risks; (2) Attention to detail; (3) Resultsoriented; (4) Human-oriented; (5) Team oriented; (6) Aggressive; and (7) Stable. Based on the seven indicators, it can be said that the organizational culture in the Pariaman City Office of Communication and Information Office Pariaman City has a very good category. The indicator is taken from the 
explanation of the characteristics of organizational culture, the characteristics of the organizational culture are very closely related in influencing employee performance.

Organizational culture has a contribution in shaping employee behavior such as instilling the values and attitudes of employees in achieving organizational goals, the organization is able to operate when there are shared values. These values will guide their behavior in each process of their activities. This phenomenon will later show that these factors will guide employees in the Pariaman City Office of Communication and Information Office to become an organization that has quality and professional performance.

2. Employee Performance

The results of this study indicate that the performance of employees at Pariaman City Communication and Information Office Pariaman City is in the very good category. This result is supported by 4 (four) indicators, namely (1) Discipline of service officers, (2) Responsibilities of service officers, (3) Ability of service officers, (4) Courtesy and friendliness of officers. Through quality by showing a good level of quality performance, with quantity then a lot of work is completed using a short time reality, as well as the use of appropriate time and highly respect the time so that in accordance with the western proverb that sees the time wasted as bad as by wasting money free of charge, and through cooperation the work done is easier and faster to complete. Of the four aspects have represented how the performance of employees produced by employees during work.

3. The Influence of Organizational Culture on Employee Performance

Based on the results of the analysis it can be seen that the product moment correlation which shows that there is a significant influence of organizational culture on employee performance at the Office of Communication and Information Office in Pariaman City, this means the hypothesis proposed is "It is suspected that there is an influence of organizational culture on employee performance at the Office of Communication and Information Office in Pariaman City "Was declared accepted with a strong degree of influence. This 
opinion explains that if organizational culture, including the factors that direct employee behavior in improving performance in the organization. This is consistent with the opinion (Dharma \& Akib, 2009) namely Innovation and Courage to take risks; Attention to detail; Results oriented; Human-oriented; Team oriented; Aggressive; and stable. That several factors of organizational culture can influence employees in improving their performance. But in reality in the field, there are still many things that can affect employee performance, such as office facilities and infrastructure, salary amounts and others not investigated in this research, which can affect employee performance.

\section{CONCLUSION}

Based on the results of data analysis and discussion described in the previous chapter on the influence of organizational culture on employee performance at the Office of Communication and Information Office of Pariaman City, it can be summarized as follows.

1. The description of organizational culture $(X)$ in the office of the Office of Communication and Information Technology of the City of Pariaman, City of Pariaman, is in the very good category in this case in terms of indicators such as Innovation and Courage to take risks; Attention to detail; Results oriented; Human-oriented; Team oriented; Aggressive; and stable.

2. The description of employee performance (Y) in the Office of Communication and Information Office of Pariaman City, Pariaman City, is in the very good category in terms of indicators such as Discipline of service officers, Responsibilities of service officers, Capability of service officers, Courtesy and friendliness of officers.

3. The product moment correlation test data obtained, organizational culture (X) with employee performance (Y) at the Office of Communication and Information Agency of Pariaman City has a significant value of 0.00-0.05 which means there is a significant correlation. With a squeeze $\mathrm{R}$ value of 0.399 or a large effect of 39.9 percent. This hypothesis is proven by the significant influence of organizational culture on employee performance in terms of the 
ANOVA table obtained by Fcount (29.876)> Ftable (4.06), then Ho is rejected and $\mathrm{Ha}$ is accepted, which means that there is a strong influence of organizational culture on employee performance in Pariaman City Communication and Information Office.

\section{REFERENCES}

Abdullah, I. (2003). Penelitian Berwawasan Gender dalam Ilmu Sosial. Humaniora, 15(3), 265-275.

Akib, H. (2008). Snapshot Dampak Kebijakan Publik dalam Program Pengentasan Kemiskinan. Makalah Tidak Dipublikasi. Malang.

Anak, A. K. (1995). Psikologi Perkembangan. Bandung: mandar maju.

Azizy, A. Q. A. (2007). Change management dalam reformasi birokrasi. Gramedia Pustaka Utama.

Ismail, A., Sulur, A. H., Akib, H., \& Salam, R. (2016). Snapshot of Society SocialEconomic Welfare based on Human Development Index in Polewali Mandar Regency, Indonesia. In International Conference on Public Organization VI (ICONPO VI) (pp. 847-858). Thammsat University, Tha Prachan Campus.

Marcella, J. (2004). Arsitektur \& Perilaku Manusia. Grasindo.

Mulia, R. A. (2019). Analisis Faktor-Faktor Yang Mempengaruhi Kualitas Laporan Keuangan Pemerintah Daerah (Studi Pada Pemerintah Kabupaten Pasaman Barat). Jurnal EL-RIYASAH, 9(1), 7-21.

Mulia, R. A. (2019). INFLUENCE OF PUBLIC POLICY, PARTICIPATION OF COMMUNITY AND EDUCATION LEVEL TO PUBLIC WELFARE IN PADANG PARIAMAN DISTRICT. Jurnal EL-RIYASAH, 10(1), 37-56.

Mulia, R. A. (2019). PERANAN PROGRAM KOPERASI JASA KEUANGAN SYARIAH BAITUL MAAL WAT TAMWIL (KJKS BMT) DALAM PEMBERDAYAAN PELAKU USAHA MIKRO KECIL MENENGAH DI KOTA PADANG. Ensiklopedia Sosial Review, 1(3).

Saputra, N. (2020). The Effect of Organizational Support on Work Satisfaction in Regional Secretariat Employees in Pariaman District. SocArXiv. February, 22.

Saputra, N., \& Mulia, R. A. (2020). Kontribusi Kompensasi Dan Motivasi Kerja Terhadap Kepuasan Kerja Pegawai Di Dinas Pendidikan Dan Kebudayaan Kabupaten Agam. Ensiklopedia Sosial Review, 2(1).

Moeljono, D. (2003). Beyond Leadership. Elex Media Komputindo. 
Nurbarani, M. (2009). Reformasi Birokrasi Pemerintah Kota Surakarta. UNIVERSITAS DIPONEGORO.

Robbins, S. P. (1996). Teori Organisasi: Struktur, Desain dan Aplikasi Terjemahan, PT. Prenhallindo, Jakarta. Broad Scope Timeliness Agregation Integration.

Putri, R. P. (2018). Pemeriksaan Penggabungan Gugatan Ganti Kerugian Dalam Perkara Pidana Di Pengadilan Negeri Kelas 1B Bukittinggi. Soumatera Law Review, 1(1), 176-197.

Putri, R. P. (2019). ASESMEN SEBAGAI SALAH SATU BENTUK REHABILITASI BAGI PENCANDU NARKOBA. Ensiklopedia Sosial Review, 1(1). 